\title{
Assessing the Immediate Impact of Surrounding Land Uses on the Extents of Freshwater Body over Time in Madagascar - A Demonstrative Case Study of Itasy Lake -
}

\author{
Masashi Konoshima $^{1 *}$, Tetsuji Tonda ${ }^{2}$, Ken-ichi Kamo ${ }^{3}$, Bam H. N. Razafindrabe ${ }^{1}$
}

\begin{abstract}
Unplanned land use conversion driven by increasing food demand has threatened rich forest resources and freshwater fishery resources in Madagascar as a result of increasing sedimentation. For sustainable use of freshwater fishery resources, it is important to examine the impact of land use changes on sedimentation. Severe sedimentation often fills-in and shrinks lakes. Also, sedimentation causes lakebeds to rise, which can lead to flooding and therefore affect the position of the lake's boundary, over time. Recently available historical satellite images can be useful in assessing the changes in the position of lake boundaries over time. In this study, we propose a modeling approach for evaluating the impact of surrounding land uses on the extents of Lake Itasy, in Madagascar. In order to demonstrate our approach, we utilized satellite imagery available via Google earth to obtain a historical snapshot of the lake boundary. We delineated it and combined the results with a land use map. We then conducted a simple spatial statistics analysis using a logistic regression model with time varying coefficients. Our approach quantifies the impact of surrounding land uses on varying positions of lake boundaries over time.
\end{abstract}

Keywords: Madagascar, land uses, sedimentation, logistic regression, time varying coefficients

\section{Introduction}

Madagascar as a country is endowed with rich natural resources and is considered one of the top "hotspots" of biodiversity in the world (Myers et al. 2000). The landbase is forested with native vegetation covering around 9 to 11 million hectares (The World Bank 2013). The native vegetation is among the most biologically diverse rich species in the world (Ganzhorn et al. 2014). The vegetation is unique because between $80 \%$ and $90 \%$ of the plant and animal species can only be found in Madagascar (Phillipson et al. 2006). Although Madagascar occupies only about 0.4 percent of the world's landmass area, it has about 5 percent of the global biodiversity population (The World Bank 2013).

Madagascar is one of the poorest countries in the world (Minten et al. 2009; Rakotondramaro and Andriamasy 2016), with over $80 \%$ of the population living in poverty i.e., below US $\$ 1.25$ per day (Rakotondramaro and Andriamasy 2016). The GDP of Madagascar per capita in 2012 is US\$ 447 (Mohan and Shellard 2014), which is less than one tenth the GDP per capita of Japan in 2012.

In general, poor countries with rich natural resources tend to rely heavily and solely on these resources for subsistence and income (Miteva 2019). Natural resources are often the principal source of income or the mainstay of the economy in these countries (OECD 2008). This has led to heavy depletion of these resources (Das and Sarkar 2020) of which Madagascar is not an exception. Local communities in Madagascar rely on forests for fuel, shelter, medicine, and food production. Forestry resources are under pressure due to the high demand for agricultural and grazing land, illegal logging and timber export, and charcoal production and mining. Population pressure also exacerbates the situation as it brings about the clearing of forestlands for agriculture purpose (DeCosse 2001; Raik 2007; Freudenberger and Freudenberger 2002) which in turn threatens biodiversity in Madagascar's forests (The World Bank 2013).

Land conversion through slash-and-burn agriculture for rice cultivation (often called as "tavy") has been one of the main causes of deforestation and land degradation (Styger et al. 2007; Klein 2002) in Madagascar, where rice is the staple food. Slash-and-burn agriculture accounts for 80 to 95 percent of deforestation (The World Bank, 2013). Itasy region, which is located in the central highlands of Madagascar, is one of the most important rice growing areas because of accessibility to the capital city of Antananarivo (Andriandralambo et al. 2017). Also, Lake itasy, is the third largest

Received Apr. 13, 2021; Accepted May. 24, 2021

${ }^{1}$ University of the Ryukyus, Japan

${ }^{2}$ Prefectural University of Hiroshima, Japan

${ }^{3}$ Sapporo Medical University, Japan

*Corresponding Author: konoshim@agr.u-ryukyu.ac.jp 
lake in Madagascar and it is located in the middle of Itasy region. It serves as an important source of freshwater fisheries, which is the most popular animal protein for the Malagasy people. However, due to land conversion to rice farming, the wetland areas in the central highlands have been polluted with runoff from surrounding rice fields. Our semi-informal interview with local people (December, 2015) indicate that extinctions of freshwater fish have been occurring in this area. Around Lake Alaotra, the country's largest lake located in East-central highlands, the streams and rivers have been clogged due to deforestation of surrounding forests. Historical satellite images show that Lake Alaotra had shrunk to $20 \%$ of its former size by 2000 (Bakoariniaina et al. 2006).

The threat against sustainable use of fisheries resources posed by land conversion has been a growing concern for local communities in Itasy region. As a result, there is a pressing need for land use planners to consider the potential impact of land conversion on sedimentation. In order to develop an appropriate land use plan, it is necessary to evaluate the effect of surrounding land uses on sedimentation.

Severe sedimentation could result in diminishing lake size. Also, sedimentation causes lake bed to rise, which could result in flooding. Therefore, monitoring the extent of a lake boundary over time could provide useful information for assessing sedimentation. Although, field surveys have often been applied to monitor periodic changes in the positions of the lake's boundary (intersection between water surface and land) with high accuracy, these approaches are often labor-intensive, timeconsuming and expensive (Liu et al. 2007; Natesan et al. 2013; Elnabwy et al. 2020). Recent studies show that sedimentation can be accessed by monitoring historical water boundary changes using Remote Sensing and Geographical Information Systems (GIS) techniques (Duru 2017). Acquiring data on spatial extent and temporal duration for evaluating changes on the shoreline of inland freshwater bodies and land use changes has become an easier task due to freely available remote sensing images. For example, Google Earth has provided historical satellite imagery in Google Earth's imagery archive which includes satellite imagery from various sources such as Landsat and MODIS (Woodcock et al. 2008). This kind of publicly available imagery archive allows us to develop land use maps in multiple time periods.

Over the past decade, a growing number of studies have used satellite imagery to assess land use changes and deforestation in Madagascar (Vågen 2006; Grinand et al. 2013; Elmqvist et al. 2007). In addition, a few studies have attempted to evaluate the impact of land use changes on sedimentation. Maina et al. (2013) used existing simulation models calibrated for Madagascar, to project the impact of land use changes on sediment yields in four watersheds, adjacent to major coral reefs. Their study showed that forest conversion increases sediment yield on those coral reefs. Although several studies have been conducted on soil erosion or sedimentation on Itasy lake, only a few of these studies have examined the effect of land uses on sedimentation or the extent of Itasy lake.

In this study, we utilize freely available satellite imagery via Google earth to propose a simple spatial logistic model with time varying coefficients to quantify the impact of immediate surrounding land uses on the extent of the lake over time. Our study demonstrates how a time varying coefficient model and publicly available historical satellite image data can be utilized in order to analyze the impact of land use change on the shoreline of inland freshwater bodies over time. The case study serves to illustrate the feasibility of our proposed modeling approach.

From statistical modeling perspective, despite the numerous application of time varying coefficient models (Tonda et al. 2011; Satoh et al. 2016; Alan et al. 2017) by Hastie and Tibshirani (1993), there is a limited application of this modeling approach to land use conversion risk. Although logistic regression models have been extensively used to predict the risk of the land use conversion for a particular parcel of land, these studies do not allow the regressors to be varied over time (Petit and Firbank 2006; Müller et al. 2011). However, the risk of land use conversion could be varied over time due to various factors. The approach utilized here allows us to quantify the longitudinal effect of independent variables (surrounding land uses) on the extents of the lake over time.

\section{Methods}

\subsection{Study area}

Our study area lies between the latitudes $19^{\circ} 11^{\prime} 18^{\prime \prime} \mathrm{S}$ to $19^{\circ} 5^{\prime} 55^{\prime \prime} \mathrm{S}$ and longitudes $46^{\circ} 44^{\prime} 1^{\prime \prime}$ $\mathrm{E}$ to $46^{\circ} 49^{\prime} 46^{\prime \prime} \mathrm{E}$ and covers an area of about 3,500 ha (Figure 1). In this study, we extract the 
area representing the intersection of the lake's water surface and its surrounding land in order to analyze the impact of the immediate surrounding of the land uses around the lake (Figure 2). Land uses of these intersection areas are classified into four different land uses, namely; water, rice field, agriculture crop production and grassland.

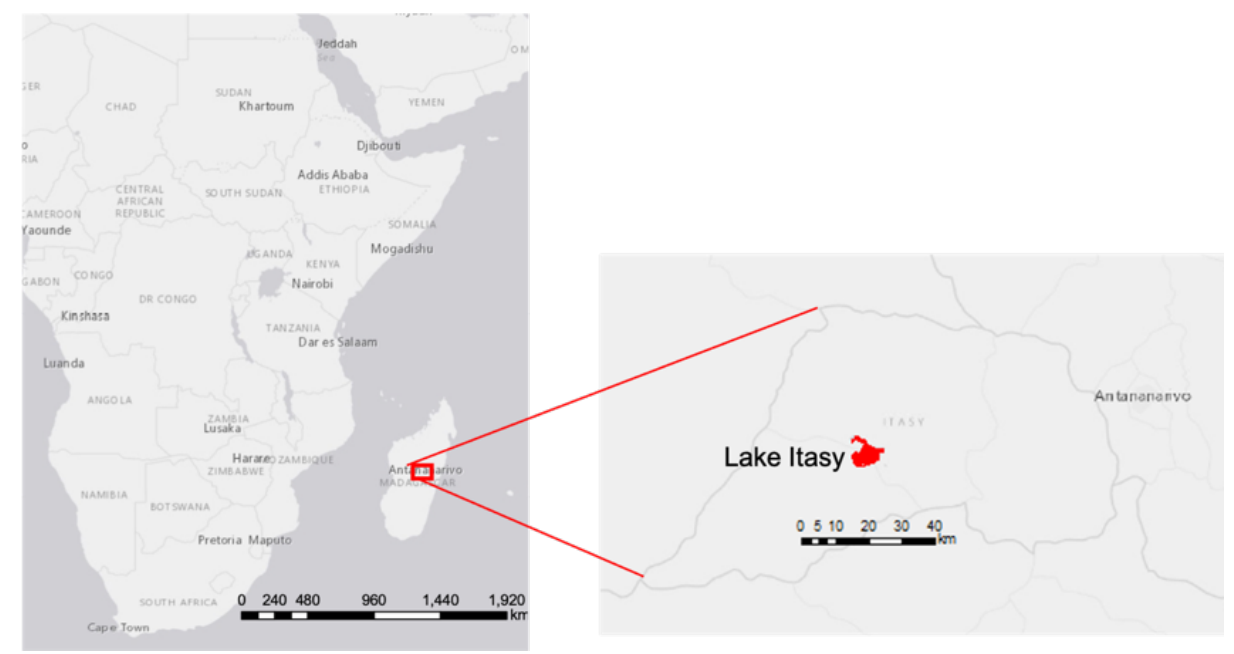

Figure 1. Location of the study area.

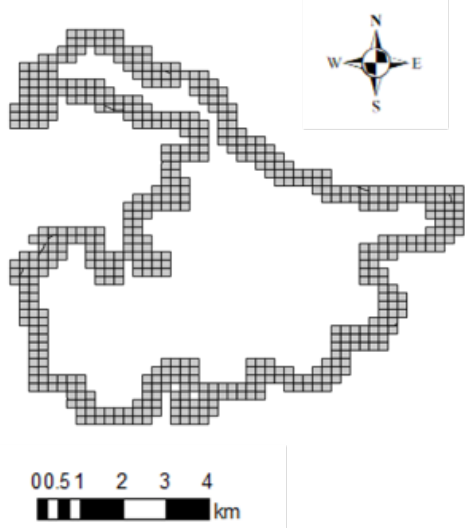

Figure 2. Intersection of the lake's water surface and its surrounding land (Shoreline).

\subsection{Data}

We downloaded 10 satellite images of 2003 (8/31), 2005(7/22, 10/15), 2009(9/22, 11/24), $2012(12$ /3), $2013(5 / 11,5 / 16,7 / 15,12 / 23)$ from Google earth for the demonstration of our proposed approach. We manually digitized the shoreline of the lake to monitor the changes in the lake's shoreline over time. We developed a grid-cell (raster) model, which is a relatively simple approach for representing spatial data. Each cell of the gird-cell model was coded according to the predominant land use in each cell. For illustration purpose we set the size of the grid as $200 \mathrm{~m} \times 200 \mathrm{~m}$. In order to estimate changes in shoreline of the lake, each image is classified into different land use classes, based on water or other land uses so that lake surface and surrounding ground can be precisely separated. All grid cells (a total of 560 cells) were used in developing the statistical model.

\subsection{Model}

We first begin with a conventional logistic model with coefficients which do not vary with time. Let $p_{i}$ represent the probability of a grid cell $i$ being part of the lake. The relationship between the land use types of eight adjacent grid cells of grid $i$ and the probability of occurrence of lake in grid 
cell $i$ can be described using a multivariate logistic regression model (Kleinbaum and Klein 2010).

$$
\log \frac{p_{i}}{1-p_{i}}=\beta_{0}+\beta_{1} s_{i}+\beta_{2} r_{i}+\beta_{3} m_{i}
$$

In order to consider a scenario where the probability can be varied over time, let $p_{i}(t)$ represent the probability of a grid cell $i$ at time $t\left(=t_{0}, t_{1}, \cdots, t_{m}\right)$ being the part of the lake. The relationship between the land use types of eight adjacent grid cells of grid $i$ at time $t_{0}$ and the longitudinal change in the probability of the occurrence of a lake in grid cell $i$ can be described using the following multivariate logistic regression model:

$$
\log \frac{p_{i}(t)}{1-p_{i}(t)}=\beta_{0}(t)+\beta_{1}(t) s_{i}+\beta_{2}(t) r_{i}+\beta_{3}(t) m_{i}
$$

where $s_{i}$ represents a dummy variable which takes on a value of 1 if adjacent grid cells contain a grassland, and 0 if otherwise. Similarly, $r_{i}$ represents a dummy variable which takes on a value of 1 if adjacent grid cells contain rice field, and 0 if otherwise. Finally, $m_{i}$ represents a dummy variable which takes on a value of 1 if adjacent grid cells contain agricultural crop production, and 0 if otherwise. $\beta_{j}(t)$ are time varying coefficients (Hastie and Tibshirani 1993) which represent the impacts of adjacent land uses. Assume the following functional form for $\beta_{j}(t)$

$[3]$

$$
\beta_{j}(t)=\boldsymbol{\theta}_{j}^{\prime} \boldsymbol{x}(t)
$$

where $\boldsymbol{x}(t)$ is a vector of a basis function used to describe the shape of $\beta_{j}(t)$. For example, $\boldsymbol{x}(t)=(1, t)^{\prime}$ if we assume a linear trend on impact of adjacent land use. Then, unknown parameters $\boldsymbol{\theta}_{j}$ can be estimated as interactions between bases $\boldsymbol{x}(t)$ and covariates, $s_{i}, r_{i}, m_{i}$ through maximum likelihood estimation (Satoh et al. 2009). Our proposed model is built upon the study by Satoh et al. (2009) who developed a methodology for estimating time varying coefficients based on conventional multivariate analysis procedures by expressing time varying coefficients in the form of $\boldsymbol{\theta}_{j}^{\prime} \boldsymbol{x}(t)$. By introducing $\beta_{j}(t)$ in a logistic regression model, this model allows us to estimate longitudinal effects of adjacent land uses. The methodologically interested reader is referred to Satoh et al. (2009) for more detail understanding. In order to explore the best model for the shape of $\beta_{j}(t)$, we perform variable selection based on AIC (Akaike 1973). Statistical analysis was conducted using R software (R Development Core Team 2011).

\section{Results}

Figure 3 shows the changing positions of the lake's shoreline (changes in the intersection of a lake's water surface and its surrounding land). As depicted in Table 1, dominant land uses at the intersection of a lake's water surface and its surrounding land has been water $(47-51 \%)$ and rice field $(26-28 \%)$.

Table 2 summarizes the results from assuming a linear function for the functional form of $\beta_{j}(t)$ in the model [1]. Table 3 summarizes the results of the optimal model using minimize AIC to select the structure of $\beta_{j}(t)$. The hyphen sign "-" represents the variables removed based on AIC model selection. As Table 3 shows, the probability that adjacent grids of the lake were classified as "water" in 2003(August) is $88 \%(\mathrm{p}<0.001)$. No change in the land use classes was detected ( $\mathrm{p}=0.672$ ). The probability that the adjacent grids of agriculture crop production or grassland were classified as "water" in 2003 (August) is significantly lower (the odds ratio for agriculture crop production and grassland were $\exp (-2.097) \approx 0.123$, and $\exp (-1.860) \approx 0.156$, respectively) compared with the case where the adjacent grids of the lake. And "time constant" models were selected for the structure for these time varying coefficients. The probability that the adjacent grids of rice fields was classified as "water" in 2003 (August) is significantly lower (the odds ratio was $\exp (-1.487) \approx 0.226$ ) compared with the case where the adjacent grids are the lake. The model capturing the increasing risk of converting to the lake over time was selected (the odds ratio was $\exp (0.028) \approx 1.028$ ).

Figure 4 shows the longitudinal change of the risk that the grid adjacent to the rice field changes to lake, and the dotted line is the $95 \%$ simultaneous confidence interval. Odds ratio show that the risk of conversion to a lake increases over time if the surrounding areas are rice fields. 
Assessing the Immediate Impact of Land Uses on the Extents of Freshwater Body

Table 1. Changes in the number of grids of each land use.

\begin{tabular}{lccccccccccc}
\hline & 2003 & 2005 & 2005 & 2009 & 2009 & 2012 & 2013 & 2013 & 2013 & 2013 \\
& $08-31$ & $07-22$ & $10-15$ & $09-22$ & $11-24$ & $12-03$ & $05-11$ & $05-16$ & $07-15$ & $12-23$ \\
\hline Rice field & 154 & 153 & 156 & 148 & 143 & 146 & 152 & 153 & 159 & 151 \\
Agriculture & 62 & 67 & 61 & 52 & 56 & 57 & 54 & 57 & 53 & 50 \\
Grassland & 80 & 78 & 78 & 75 & 76 & 75 & 76 & 76 & 72 & 77 \\
Water & 264 & 262 & 265 & 285 & 285 & 282 & 278 & 274 & 276 & 282 \\
\hline
\end{tabular}

Table 2. Parameters estimation based on linear $\beta_{j}(t)$.

\begin{tabular}{ccccc}
\hline & & Estimate & S.E & p value \\
\hline \multirow{2}{*}{ Water $\beta_{0}(t)$} & Intercept & 2.057 & 0.138 & $<0.001$ \\
& Slope & 0.001 & 0.018 & 0.971 \\
Agiruclure $\beta_{1}(t)$ & Intercept & -2.096 & 0.145 & $<0.001$ \\
& Slope & 0.000 & 0.019 & 0.998 \\
Rice field $\beta_{2}(t)$ & Intercept & -1.488 & 0.144 & $<0.001$ \\
& Slope & 0.028 & 0.019 & 0.138 \\
Glassland $\beta_{3}(t)$ & Intercept & -1.934 & 0.147 & $<0.001$ \\
& Slope & 0.011 & 0.019 & 0.569 \\
\hline
\end{tabular}

Table 3. Parameters estimation based on AIC model selection for $\beta_{j}(t)$ structure.

\begin{tabular}{ccccc}
\hline & & Estimate & S.E & p value \\
\hline \multirow{2}{*}{ Water $\beta_{0}(t)$} & Intercept & 2.039 & 0.086 & $<0.001$ \\
& Slope & 0.003 & 0.008 & 0.672 \\
Agiruclure $\beta_{1}(t)$ & Intercept & -2.097 & 0.071 & $<0.001$ \\
& Slope & - & - & - \\
Rice field $\beta_{2}(t)$ & Intercept & -1.487 & 0.126 & $<0.001$ \\
& Slope & 0.028 & 0.016 & 0.077 \\
Glassland $\beta_{3}(t)$ & Intercept & -1.860 & 0.072 & $<0.001$ \\
& Slope & - & - & - \\
\hline
\end{tabular}



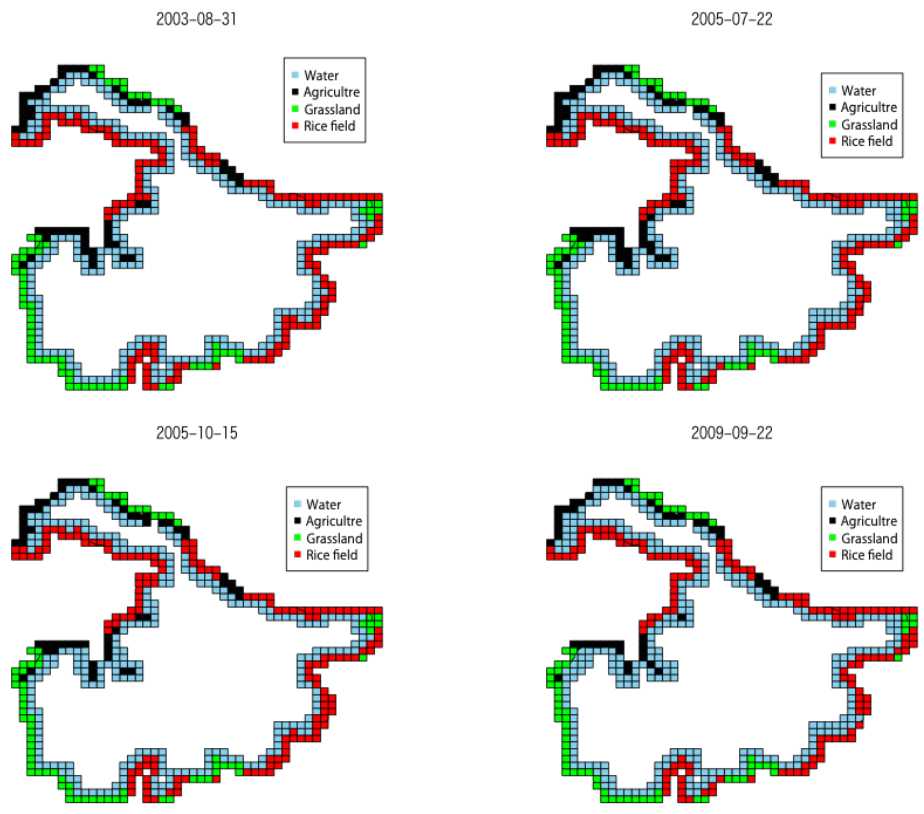

2009-11-24
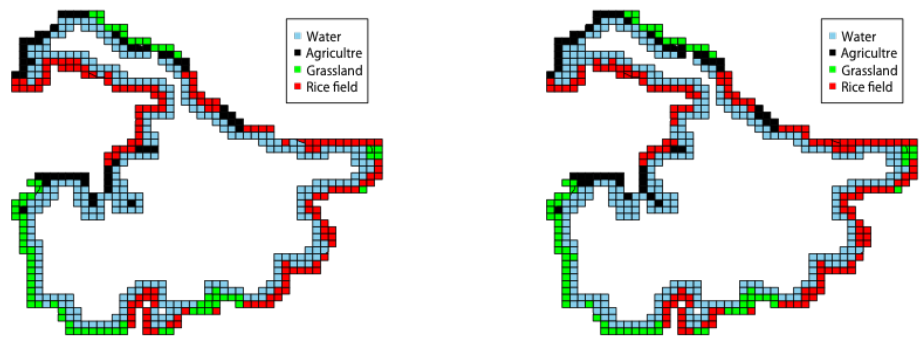

2013-05-11
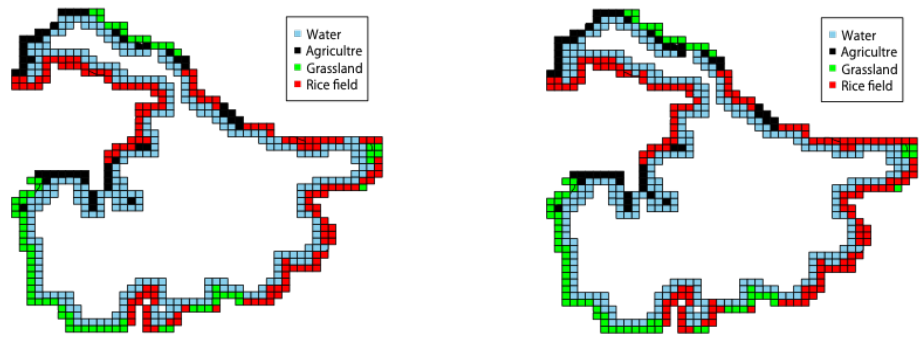

2013-07-15

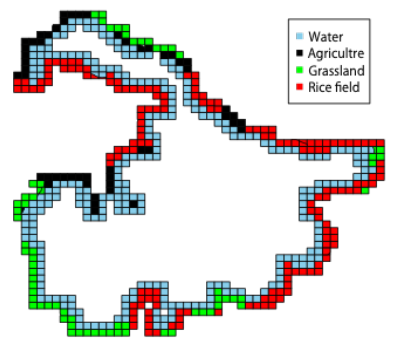

2013-12-23

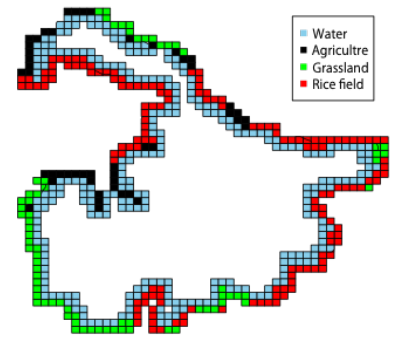

Figure 3. Changes in the intersection of a lake's water surface and its surrounding land over time. 


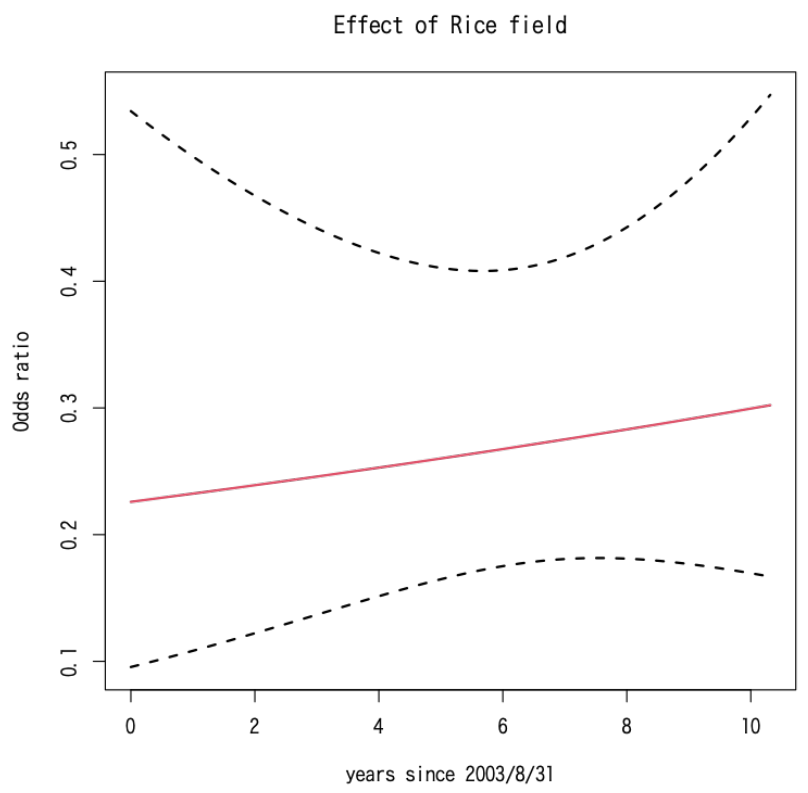

Figure 4. Longitudinal effect of adjacent rice field on the risk of being converted to lake.

\section{Discussion and Conclusions}

Inland fishery based on lacustrine fisheries is important resources in Madagascar where people rely on fish for animal protein (Breuil and Grima 2014). However, sedimentation caused by deforestation and agriculture development in the basin areas has led to serious environmental problems in freshwater bodies in Madagascar (Breuil and Grima 2014). One of the most concerned land conversions is slash and burn agriculture for rice cultivation which has been triggered by the increasing demand for rice, the main staple food for the people of Madagascar, due to rapid population growth (annual population growth of $2.9 \%$ between 2005 to 2010 as reported by the United Nations (UNFPA 2012) in Madagascar. Expansion of rice fields to meet increasing demand undermines fishery production which is an important source of animal protein. Although, it has been a while since rice-fish farming system (which is growing fish and rice simultaneously), was introduced in Madagascar. This system has not been implemented extensively (Halwart 1998) and is far from being an effective tool for addressing this issue. It is important to develop land use plan considering the effect of land use on sedimentation in freshwater bodies in Madagascar.

Detecting and monitoring the changes in shoreline of the lake (changes in the intersection of a lake's water surface and its surrounding land) are essential for sustainable lake resource management because sedimentation often affect the surface area of lake. The extent of soil erosion and sedimentation in the area may increase as Itasy region is considered to be among the areas with the highest rate of deforestation in the previous decades (IMF 2009). Agricultural practices located on steep slopes, as well as frequent wild fires occurring in the region are the main causes of soil erosion and sedimentation bordering the lake (MAEP 2006). Integrating this temporal information with land use map, allows us to analyze the impact of land use on the extents of the lake. In this study, we utilized historical satellite images of the lake boundary and combined that with land use map in order to evaluate the impact of land uses on the extent of the lake, in Madagascar.

We develop a simple logistic model with time varying coefficients for land conversion in Itasy region, which includes Madagascar's third largest lake, Lake Itasy. It is one of the most productive rice growing areas. This study is among the pioneers in attempting to quantify the impact of immediate surrounding of land uses on the extents of the lake in Itasy region, over time. Our approach is constrained by the limitations of currently available satellite imagery provided via Google earth. For simple demonstration purpose of our approach, we used the data from Google earth without accessing the original data source information (such as the type of censor used, atmospheric correction, cloud score etc., ) because Google earth provides already processed images for easy 
visualization (Magaña et al. 2014; Kumar and Mutanga 2018). Future studies should carefully consider accessing the original data source of images used so that numerical results obtained could be more meaningful, than just an illustration of the modeling approach. In addition, we relied on a manual digitizing method to detect the shoreline. Although by combining this approach with ground surveys, we can further improve the quality of shoreline position detection (Li et al. 2002). These approaches are time consuming and labor intensive. Various classification techniques have been proposed to automatically detect water and non-water objects (Dewi et al. 2016). For example, Dewi et al. (2016) developed a fuzzy classification method for detecting changes in shoreline by explicitly considering a transition zone between water and non-water objects, and their imprecise boundaries. Future studies can utilize these techniques to improve the quality of a database and the efficiency of database development process so that more satellite images from other sources other than a free application can be included for the analysis.

Also, for illustration purpose, we set various assumptions to simplify the problem. For example, we conducted a statistical analysis based only on a grid size of $200 \mathrm{~m}$. In future studies, we can develop land use data at various resolutions and explore the effects of grid size on our statistical analysis, which will allow us to find the reasonable grid size for the analysis (Bormann 2006).

Our results did not show any significant longitudinal effects of adjacent land uses. Considering only adjacent land uses may not be enough to successfully capture factors that affect changes in the shoreline (position of water boundaries) of the lake. In this study, we focused on land uses adjacent to the lake. These immediate surrounding areas of the lake contain similar topographic conditions because all sites are on gentle slope directed downward towards the lake. However, in order to identify longitudinal effects of land uses on the extent of water boundaries, it will be important to expand the area over immediate surrounding of the lake so that we can evaluate the impact of spatial patterns of the land uses as well as topographic conditions of sedimentation on the lake. Also, future studies should consider seasonal effects such as rain events.

Due to these limitations and simplifications in our modeling approach, the results must be thoroughly verified before it is used for any land management plans. Rather our results should be taken as an indication of the need for further analysis with additional supplementary data.

Despite these limitations, our study demonstrates how publicly available satellite image archive can be used to develop a data set required for statistical analysis, and shows how a time varying coefficient model can be used to quantify the impact of immediate surrounding land uses on the extents of the lake over time. Through our personal communication with local people (December 2015), we found that local people have been feeling the threat against sustainable use of fishery resources that pose periodic changes to water boundaries. Assessing the impact of surrounding land uses on the extent of water boundaries is the first step toward developing effective measure against serious sedimentation. This study shows that our approach can quantify the effect of surrounding land uses on the extent of water boundaries and can be a useful approach in the development of land use plans. Finally, this study provides an avenue for future researchers to conduct a quick assessment of the effect of surrounding land uses on the extent of a lake, with relatively low cost modeling process. Our approach neither requires expensive software for the analysis nor high-cost satellite imagery to develop a database. In addition to freely available satellite images, $\mathrm{R}$ software, which was used to develop the logistic model with time varying coefficients, is also freely available from public domain. Hence, our approach is easily replicable in other financially-challenged regions where sufficient data are not readily available.

\section{Acknowledgement}

This research was partially supported by a Grant-in-Aid for Scientific Researches (No. 16K12641\& 17H00806) from the Ministry of Education, Culture, Sports, Science, and technology of Japan. The authors appreciate the insightful comments on earlier drafts made by anonymous reviewers.

\section{References}

Akaike, H. (1973) Information theory and an extension of the maximum likelihood principle, In: Csaki, F., Petrov, B.N. (eds.) Proceedings of the 2nd International Symposium on Information Theory; Budapest: Akademiai Kiado: 267-281. 
Andrianampiarivo, T. (2016) Moderate prosperity, an adaptation of the middle class concept to a Malagasy rural area: the case of Itasy, Rev. Soc. Econ. 75(1): 26-48.

Bakoariniaina, L.N., Kusky, T., Raharimahefa, T. (2006) Disappearing Lake Alaotra: Monitoring catastrophic erosion, waterway silting, and land degradation hazards in Madagascar using Landsat imagery, J. Afr. Earth Sci. 44: 241-252.

Benstead, J.P., De Rham, P.H., Gattoliat, J.L., Gibon, F.M., Loiselle, P.V., Sartori, M., Sparks, J.S., Stiassny, M.L.J. (2003) Conserving Madagascar's freshwater biodiversity, Bioscience 53: $1101-1111$.

Bormann, H. (2006) Effects of grid size and aggregation on regional scale landuse scenario calculations using SVAT schemes. Adv. Geosci. 9: 45-52.

Breuil, C., Grima, D. (2014) Baseline Report Madagascar. SmartFish Programme of the Indian Ocean Commission, Fisheries Management FAO component, Ebene, Mauritius. 35 pp.

Das, G., Sarkar, R. (2020) Global Environmental Challenges in the 21st Century In: Sarkar, R. (ed), Environmental sustainability in the 21st century: Emerging issues and the way forward, Namya Press, Delhi, India 364pp.

DeCosse, P.J. (2001) Forest governance and communications under PAGE: Rationale and strategy. Report for USAID/Madagascar, 20 November. <http://pdf.usaid.gov/pdf_docs/PNACT686.pdf > (Accessed May. 6, 2021).

Dewi, R.S., Bijker, W., Stein, A., Marfai, M.A. (2016) Fuzzy classification for shoreline change monitoring in a part of the northern coastal area of Java, Indonesia. Remote Sens. 8(3): 190.

Duru, U. (2017) Shoreline change assessment using multi-temporal satellite images: a case study of Lake Sapanca, NW Turkey. Environ. Monit. Assess. 189(8): 1-14.

Elmqvist, T., Pyykönen, M., Tengö, M., Rakotondrasoa, F., Rabakonandrianina, E., Radimilahy, C. (2007) Patterns of loss and regeneration of tropical dry forest in Madagascar: the social institutional context. Plos One 2(5): e402.

Elnabwy, M.T., Elbeltagi, E., El Banna, M.M., Elshikh, M.M., Motawa, I., Kaloop, M.R. (2020) An Approach based on Landsat images for shoreline monitoring to support integrated coastal management-a case study, Ezbet Elborg, Nile Delta, Egypt, ISPRS Int. J. Geo-Inf. 9(4): 199.

Freudenberger, M., Freudenberger, K. (2002) Contradictions in agricultural intensification and improved natural resource management: Issues in the Fianarantsoa forestcorridor of Madagascar. Barrett, CB, Place, F., Aboud, AA, Natural Resources Management in African Agriculture: Understanding and Improving Current Practices, Wallingford, CABI Publishing/International Centre for Agroforestry, 181-192.

Ganzhorn, J.U., Wilmé, L. Mercier, J.L. (2014) Explaining Madagascar's biodiversity In: Scales, I.R. (ed), Conservation and environmental management in Madagascar, Routledge. 17-43.

Grinand, C., Rakotomalala, F., Gond, V., Vaudry, R., Bernoux, M., Vieilledent, G. (2013) Estimating deforestation in tropical humid and dry forests in Madagascar from 2000 to 2010 using multi-date Landsat satellite images and the random forests classifier, Remote Sens. Environ. 139: $68-80$.

Halwart, M. (1998). Trends in rice-fish farming. FAO Aquaculture Newsletter 18(3): C11.

Hastie, T., Tibshirani, R. (1993) Varying-coefficient models, J. Roy. Statist. Soc. Ser. B, 55: 757-796.

IMF (International Monetary Fund) (2009) Republic of Madagascar: Poverty Reduction Strategy Paper-Annual Progress Report for 2007 and First Semester of 2008. IMF Country Report No. 09/10. 47pp. <https://www.imf.org/external/pubs/ft/scr/2009/cr0910.pdf> (Accessed 6 May, 2021) 
Klein, J. (2002) Deforestation in the Madagascar highlands - established truth' and scientific uncertainty. GeoJournal 56(3): 191-199.

Kleinbaum, D. G. and Klein, M. (2010) Logistic Regression: A Self-Learning Text, Springer-Verlag, New York, 719p.

Kumar, L., Mutanga, O. (2018) Google Earth Engine applications since inception: Usage, trends, and potential, Remote Sens. 10(10): 1509.

Li, R., Ma, R., Di, K. (2002) Digital tide-coordinated shoreline, Mar. Geod. 25(1-2): 27-36.

Liu, H., Sherman, D., Gu, S. (2007) Automated extraction of shorelines from airborne light detection and ranging data and accuracy assessment based on Monte Carlo simulation, J. Coast. Res. 23(6(236)): 1359-1369.

MAEP (Ministry of Agriculture, Animal Husbandry and Fisheries) (2006) BVPI Watershed Management Project: Social and Environmental Evaluation of Itasy site. 42pp. (in French)

Magaña, P., López-Ruiz, A., Lira, A., Ortega-Sánchez, M., Losada, M. A. (2014) A public, open Western Europe database of shoreline undulations based on imagery, Appl. Geogr. 55: 278-291.

Maina, J., De Moel, H., Zinke, J., Madin, J., McClanahan, T., Vermaat, J. E. (2013) Human deforestation outweighs future climate change impacts of sedimentation on coral reefs, Nat. Commun. 4(1): 1-7.

Minten, B., Randrianarison, L., Swinnen, J.F. (2009) Global retail chains and poor farmers: Evidence from Madagascar, World Dev. 37(11): 1728-1741.

Miteva, D.A. (2019) The integration of natural capital into development policies, Oxf. Rev. Econ. Policy 35(1): 162-181.

Mohan, V., Shellard, T. (2014) Providing family planning services to remote communities in areas of high biodiversity through a Population-Health-Environment programme in Madagascar, Reprod. Health Matters 22(43): 93-103.

Müller, R., Müller, D., Schierhorn, F., Gerold, G. (2011) Spatiotemporal modeling of the expansion of mechanized agriculture in the Bolivian lowland forests, Appl. Geogr. 31(2): 631-640.

Myers, N., Mittermeier, R.A., Mittermeier, C.G., Da Fonseca, G.A., Kent, J. (2000) Biodiversity hotspots for conservation priorities, Nature 403(6772): 853-858.

Natesan, U., Thulasiraman, N., Deepthi, K., Kathiravan, K. (2013) Shoreline change analysis of Vedaranyam coast, Tamil Nadu, India, Environ. Monit. Assess. 185(6): 5099-5109.

OECD (Organisation for Economic Co-operation and Development) (2008) Natural Resources and Pro-Poor Growth: The Economics and Politics. Paris: OECD Publishing.

Petit, S., Firbank, L. (2006) Predicting the risk of losing parcels of semi-natural habitat to intensive agriculture, Agric. Ecosyst. Environ. 115(1-4): 277-280.

Phillipson, P.B., Schatz, G.E., Lowry II, P.P. Labat J.N. (2006) A catalogue of the vascular plants of Madagascar, In: Ghazanfar, S.A., Beentje, H.J. (eds.), Taxonomy and ecology of African plants, their conservation and sustainable use, pp. 613 - 627. Royal Botanic Gardens, Kew.

R Development Core Team (2011) R: A language and environment for statistical computing. R Foundation for Statistical Computing, Vienna, Austria. Available in: <http://www.r-project.org $>$

Raik, D. (2007) Forest management in Madagascar: An historical overview, Madag Conserv. Dev. $2(1)$.

Rakotondramaro, H., Andriamasy, L. (2016) Multivariate Granger Causality among tourism, poverty and growth in Madagascar, Tour. Manag. Perspect 20: 109-111. 
Satoh, K., Yanagihara, H., Kamo, K. (2009) Statistical inference on a linear varying coefficient on longitudinal data of discrete distribution, Japanese J. Appl. Statist. 38: 1-11 (in Japanese).

Satoh, K., Tonda, T., Izumi, S. (2016) Logistic regression model for survival time analysis using time-varying coefficients, Am. J. Math. Manag. Sci. 35(4): 353-360.

Styger, E., Rakotondramasy, H.M., Pfeffer, M.J., Fernandes, E.C., Bates, D.M. (2007) Influence of slash-and-burn farming practices on fallow succession and land degradation in the rainforest region of Madagascar. Agric. Ecosyst. Environ. 119(3-4): 257-269.

Tonda, T., Satoh, K., Nakayama, T., Katanoda, K., Sobue, T., Ohtaki, M. (2011) A Nonparametric mixed-effects model for cancer mortality, Aust. N.Z. J. Stat. 53(2): 247-256.

UNFPA, 2012. Madagascar. Country Implementation Profile. International Conference on Population and Development Beyond $2014<$ https://www.unfpa.org/sites/default/files/resource-pdf/ FINAL_Madagascar.pdf $>$ (Accessed 25 January, 2021)

Vågen, T.G. (2006) Remote sensing of complex land use change trajectories - a case study from the highlands of Madagascar, Agric. Ecosyst. Environ. 115(1-4): 219-228.

Wan, A.T., Xie, S., Zhou, Y. (2017) A varying coefficient approach to estimating hedonic housing price functions and their quantiles, J. Appl. Stat. 44(11): 1979-1999.

Woodcock, C.E., Allen, R., Anderson, M., Belward, A., Bindschadler, R., Cohen, W., Gao, F., Goward, S.N., Helder, D., Helmer, E. (2008) Free access to landsat imagery, Science 320: 1011.

The World Bank (2013) Madagascar Country Environmental Assessment (CEA), Taking Stock and Moving Forward. 139pp. 